\title{
PENGARUH TUNJANGAN FUNGSIONAL TERHADAP MOTIVASI KERJA PUSTAKAWAN DI PERPUSTAKAAN IAIN CURUP
}

\author{
Desti Dwi Putri \\ Program Studi Ilmu Perpustakaan \\ Fakultas Adab dan Humaniora \\ Universitas Islam Negeri Raden Fatah Palembang \\ Email: destidwiputrigunarto@gmail.com
}

\begin{abstract}
Abstrak
Penelitian ini bertujuan untuk mengetahui adakah pengaruh tunjangan fungsional terhadap motivasi kerja pustakawan diperpustakaan IAIN Curup, dan seberapa besar pengaruh tunjangan fungsional terhadap motivasi kerja pustakawan di Perpustakaan IAIN Curup. Penelitian ini merupakan penelitian korelasional dengan pendekatan kuantitatif. Metode pengumpulan data menggunakan observasi, wawancara, kuesioner, dan dokumentasi. Populasi dalam penelitian ini ialah pustakawan di perpustakaan IAIN Curup sebanyak 6 orang, kemudian seluruh populasi dijadikan sampel. Teknik penentuan sampel menggunakan teknik sampel jenuh. Pengukuran data dalam penelitian ini menggunakan skala likert. Teknik analisis data menggunakan pengujian hipotesis, regresi linier sederhana, uji signifikansi parsial (Uji T), uji koefisien determinasi, dan uji normalitas.

Hasil penelitian menunjukkan bahwa tunjangan fungsional di perpustakaan IAIN Curup terdapat pengaruh positif dan signifikan antara tunjangan fungsional terhadap motivasi kerja pustakawan dan besarnya pengaruh tunjangan fungsional terhadap motivasi kerja pustakawan sebesar 97,1\%.
\end{abstract}

Kata kunci: Tunjangan Fungsional, Motivasi Kerja

\begin{abstract}
This study aims to determine whether there is an effect of functional allowances on librarians 'work motivation in the IAIN Curup library, and how much influence the functional allowances on librarians' work motivation in the IAIN Curup Library. This research is a correlational research with a quantitative approach. Data collection methods using observation, interviews, questionnaires, and documentation. The population in this study were librarians in the IAIN Curup library of 6 people, then the entire population was sampled. The sampling technique uses saturated sample technique. Measurement data in this study using a Likert scale. Data analysis techniques used hypothesis testing, simple linear regression, partial
\end{abstract}


significance test ( $T$ test), coefficient of determination test, and normality test.

The results showed that functional allowances in Curriculum IAIN library there was a positive and significant effect between functional allowances on the work motivation of librarians and the magnitude of the influence of functional allowances on work motivation of librarians was $97.1 \%$.

Keywords: Functional Benefits, Work Motivation 


\section{Pendahuluan}

\section{$1.1 \quad$ Latar Belakang}

Perpustakaan perguruan tinggi ialah perpustakaan yang terdapat pada peguruan tinggi, dengan tujuan utama membantu perguruan tinggi mencapai tujuannya. Perpustakaan perguruan tinggi benar-benar berada di suatu perguruan tinggi, baik berbentuk universitas, akademik, sekolah tinggi, atau pun institut. Keberadaan, tugas dan fungsi perpustakaan tersebut adalah dalam rangka melaksanakan Tri Dharma Perguruan Tinggi, meliputi pendidikan, penelitian / riset dan pengabdian kepada masyarakat. ${ }^{24}$

Untuk menunjang Tri Dharma Perguruan Tinggi Tersebut Perpustakaan sebagai pusat sumber informasi tidak lepas dari pengelolanya yaitu pustakawan. Menurut Undang-Undang Nomor 43 Tahun 2007 tentang perpustakaan mendefinisikan pustakawan adalah "seseorang yang memiliki kompetensi yang diperoleh melalui pendidikan dan/atau pelatihan kepustakawanan serta mempunyai tugas dan tanggung jawab untuk melaksanakan pengelolaan dan pelayanan perpustakaan".25 Sedangkan menurut PERMENPAN Nomor 9 Tahun 2014 bahwa pustakawan adalah Pegawai Negeri Sipil (PNS) yang diberi tugas, tanggung jawab, wewenang, dan hak untuk melaksanakan kegiatan kepustakawanan. ${ }^{26}$

Untuk melaksanakan kegiatan kepustakawanan tersebut maka tugas pokok Pustakawan yaitu melaksanakan kegiatan di

\footnotetext{
${ }^{24}$ Sutarno NS, Manajemen Perpustakaan : Suatu Pendekatan Praktik (Jakarta: Sagung Seto, 2006), h. xvi.

${ }^{25}$ Undang-Undang Republik Indonesia No. 43 Tahun 2007 : Tentang Perpustakaan. ( Jakarta: Perpustakaan Nasional RI, 2007), h.2

${ }^{26}$ Peraturan Menteri Pendayagunaan Aparatur Negara dan Reformasi Birokrasi Republik Indonesia Nomor 9 Tahun 2014 : Tentang Jabatan Fungsional Pustakawan dan Angka Kreditnya. ( Jakarta: Perpustakaan Nasional RI, 2007), h.4
} 
bidang Kepustakawanan yang meliputi Pengelolaan Perpustakaan, Pelayanan Perpustakaan, dan Pengembangan Sistem Kepustakawanan. ${ }^{27}$

Perlu diketahui bahwa macam-macam pustakawan itu terdiri dari pustakawan pertama, muda, madya, utama. Dari beberapa macam pusakawan ini mereka mempunyai tugas yang berbeda- beda sesuai dengan tingkatannya masing-masing, misalnya antara pustakawan ahli dan pustakawan terampil, diantaranya tugas pokok pustakawan tingkat terampil yaitu pengorganisasian dan pendayagunaan koleksi bahan pustaka, permasyarakatan perpustakaan dokumentasi dan informasi. Sedangkan tugas pustakawan tingkat ahli yaitu mengumpulkan data untuk persiapan perencanaan penyelenggaraan perpustakaan, mengidentifikasi koleksi perpustakaan, melakukankatalogisasi deskriftif bahan perpustakaan tingkat tiga, dan lain-lain. ${ }^{28}$ Perpustakaan perguruan tinggi biasanya harus ada pustakawan ahli dan pustakawan terampil. Karena ini bisa dikatakan pustakawan tingkat tinggi dan mempunyai tugas yang lebih besar dibanding pustakawan lainnya.

Untuk menjalankan tugas pustakawan tersebut maka perlu adanya motivasi bagi para pustakawan. Motivasi adalah keadaan dalam diri individu yang mendorong prilaku kearah tujuan. ${ }^{29}$ Salah satu motivasi untuk memotivasi pustakawan tesebut yaitu dengan adanya tunjangan fungsional

\footnotetext{
${ }^{27}$ Hermawan, Rachman dan Zulfikar Zen, Etika Kepustakawanan: Suatu Pendekatan terhadap Kode Etik Pustakwan Indonesia. (Jakarta: Sagung Seto2006), h 50

${ }^{28}$ Peraturan Menteri Pendayagunaan Aparatur Negara dan Reformasi Birokrasi Republik Indonesia Nomor 9 Tahun 2014 : Tentang Jabatan Fungsional Pustakawan dan Angka Kreditnya. ( Jakarta: Perpustakaan Nasional RI, 2007), h.11
}

${ }^{29}$ Alhamdu fara hamdana, psikologi umum ( Palembang: Noerfikri offset,2017), h.179 
pustakawan. Tunjangan fungsional adalah sarana untuk memotivasi anggota profesi untuk bekerja secara professional. Profesi pustakawan merupakan suatu profesi yang sudah lama dikenal di Indonesia. Pengakuan profesi pustakawan diakui sejak dikeluarkannya Surat Keputusan Menteri Pendayagunaan Aparatur Negara No. 18 Tahun 1988 sebagai awal pengakuan pemerintah terhadap jabatan fungsional pustakawan. Tunjangan fungsional pustakawan diharapkan akan menjadi dorongan tersendiri sebagai pengakuan dari jabatan profesi pustakawan, tanpa adanya motivasi pustakawan dalam bekerja maka tujuan kepustakawanan tidak akan tercapai dengan baik sesuai dengan yang diharapkan. Maka dengan adanya tunjangan fungsional pustakawan diharapkan menjadi motivasi dalam diri untuk memberikan semangat kerja kepada para pustakawan dalam meningkatkan kualitas kerja. ${ }^{30}$

Menurut Peraturan Pemerintah Nomor 71 tahun 2013 Dalam Pasal 1 yang dimaksud dengan Tunjangan Jabatan Fungsional Pustakawan, yang selanjutnya disebut dengan tunjangan Pustakawan adalah tunjangan jabatan fungsional yang diberikan kepada Pegawai Negeri Sipil yang diangkat dan ditugaskan secara penuh dalam Jabatan Fungsional Pustakawan sesuai dengan ketentuan peraturan perundangundangan. ${ }^{31}$ Sedangkan menurut peraturan menteri pendayagunaan aparatur negara dan reformasi birokrasi republik indonesia nomor 9 tahun 2014 tentang jabatan fungsional pustakawan dan angka kreditnya menyatakan

\footnotetext{
${ }^{30}$ Wursanto IG, Manajemen Kepegawaian I (Yogyakarta: Kanisius, 1989), h. 132

${ }^{31}$ Peraturan Pemerintah Nomor 71 Tahun 2013: Tentang Tunjangan Jabatan Fungsional Pustakawan (Jakarta; Perpustakaan Nasional RI,2013). h.3
} 
bahwa tunjangan fungsional pustakawan adalah jabatan yang mempunyai ruang lingkup, tugas, tanggung jawab, wewenang, dan hak untuk melaksanakan kegiatan kepustakawanan. ${ }^{32}$

Perpustakaan Institut Agama Islam Negeri (IAIN) Curup merupakan salah satu perpustakaan yang diselenggarakan sebagai tempat untuk memperoleh informasi yang dibutuhkan oleh civitas akademika Institut Agama Islam Negeri (IAIN) Curup. Untuk menunjang aktivitas perpustakaan tersebut, maka Diketahui bahwa perpustakaan Institut Agama Islam Negeri (IAIN) Curup mempunyai pustakawan yang kreatif. Karena sudah banyak karya yang telah dibuat oleh pustakawan IAIN Curup baik itu buku, artikel,dan kary-karya lainnya dibutuhkan motivasi kerja pustakawan yang baik. Perpustakaan IAIN Curup memiliki 6 orang pustakawan diantara dari keenam orang putakawan tersebut 5 orang yang berlatar belakang jurusan ilu perpustakaan dan yang satunya hanya engikuti diklat.

Berdasarkan observasi 21 juli 2018 beberapa masalah yang masih sering terjadi di Perpustakaan IAIN Curup antara lain dapat dilihat masih banyak keluhan pengguna perpustakaan yang merasa tidak puas terhadap pelayanan yang diberikan oleh pustakawan. kurangnya kehadiran pustakawan di tempat kerja dapat mengakibatkan penilaian kerja yang tidak baik. ${ }^{33}$ Padahal pustakawan tersebut sudah mempunyai tunjangan. Salah satu pustakawan di Perpustakaan IAIN Curup mengungkapkan bahwa dengan adanya tunjangan fungsional

\footnotetext{
${ }^{32}$ Peraturan Menteri Pendayagunaan Aparatur Negara dan Reformasi Birokrasi Republik Indonesia Nomor 9 Tahun 2014 : Tentang Jabatan Fungsional Pustakawan dan Angka Kreditnya (Jakarta: Perpustakaan Nasional RI, 2014), h. 4

${ }^{33}$ Observasi lapangan, Curup 21 juli 2018
} 
pustakawan ini seharusnya sangat memotivasi diri untuk bekerja di perpustakaan. Akan tetapi pada kenyataannya masih ada pustakawan yang mencuri- curi waktu pada saat jam kerja untuk melakukan aktivitas lain yang tidak berhubungan dengan pekerjaan yang ada di perpustakaan. ${ }^{34}$ Hal ini menjadi permasalahan bagi peneliti untuk meneliti pustakawan yang lainnya di Perpustakaan IAIN Curup.

Berdasarkan hasil pengamatan penulis yang sudah disebutkan sebelumnya masih banyak keluhan pemustaka yang merasa tidak puas terhadap pelayanan yang diberikan oleh pustakawan. Kemudian masih ada pustakawan yang mencuri-curi waktu pada saat jam kerja untuk melakukan aktivitas lain yang tidak berhubungan dengan pekerjaan yang ada di perpustakaan. Dan fenomena-fenomena tersebut merupakan hasil temuan itulah yang melatarbelakangi penulis untuk mengetahui "Pengaruh Tunjangan Fungsional Terhadap Motivasi Kerja Pustakawan di Perpustakaan IAIN Curup dan Seberapa besar pengaruh tunjangan fungsional terhadap motivasi kerja pustakawan di perpustakaan IAIN Curup".

\subsection{Permasalahan}

Penelitian yaang akan dilakukan mengenai pengaruh tunjangan fungsional terhadap motivasi kerja pustakawan di Perpustakaan IAIN Curup akan menjawab permasalahan sebagai berikut:

a. Adakah pengaruh tunjangan fungsional terhadap motivasi kerja pustakawan di perpustakaan IAIN Curup?

${ }^{34}$ Wawancara , Palembang 4 Maret 2019 
b. Seberapa besar pengaruh tunjangan Fungsional terhadap motivasi kerja pustakawan di perpustakaan IAIN Curup?

\subsection{Tujuan}

Tujuan dalam penelitian ini dilakukan untuk:

a. mengetahui adakah pengaruh tunjangan fungsional terhadap motivasi kerja pustakawan di perpustakaan IAIN Curup

b. mengetahui seberapa besar pengaruh tunjangan fungsional terhadap motivasi kerja pustakawandi perpustakan IAIN Curup

\section{Landasan Teori}

\subsection{Tunjangan Fungsional}

Tunjangan fungsional menurut Kamus Besar Bahasa Indonesia (KBBI) Pusat Bahasa adalah uang (barang) yang dipakai untuk menunjang tamabahan pendapatan diluar gaji sebagai bantuan (sokongan) yang diberikan kepada pegawai negeri sesuai dengan pangkatnya. 35 Sedangkan menurut Surat Keputusan Presiden No. 71 Tahun 2013 Dalam Pasal 1 yang dimaksud dengan Tunjangan Jabatan Fungsional Pustakawan, yang selanjutnya disebut dengan tunjangan Pustakawan adalah tunjangan jabatan fungsional yang diberikan kepada Pegawai Negeri Sipil yang diangkat dan ditugaskan secara penuh dalam Jabatan Fungsional Pustakawan sesuai dengan ketentuan peraturan perundangundangan. ${ }^{36}$ Menurut peraturan menteri pendayagunaan aparatur negara dan reformasi birokrasi republik indonesia

${ }^{35}$ Tim Penyusun Kamus Pusat Bahasa, Kamus Besar Bahasa Indonesia (Jakarta : Balai Pustaka, 2008), h. 1505

${ }^{36}$ Peraturan Pemerintah Nomor 71 Tahun 2013: Tentang Tunjangan Jabatan Fungsional Pustakawan (Jakarta; Perpustakaan Nasional RI,2013). h.3 
nomor 9 tahun 2014 tentang jabatan fungsional pustakawan dan angka kreditnya menyatakan bahwa tunjangan fungsional pustakawan adalah jabatan yang mempunyai ruang lingkup, tugas, tanggung jawab, wewenang, dan hak untuk melaksanakan kegiatan kepustakawanan. ${ }^{37}$

Dari pengertian diatas yang dimaksud dengan tunjangan fungsional adalah uang (barang) yang dipakai untuk menunjang tamabahan pendapatan diluar gaji sebagai bantuan (sokongan) yang diberikan kepada pegawai negeri sesuai dengan pangkatnya dan tugas, tanggung jawab, wewenang, dan hak untuk melaksanakan kegiatan kepustakawanan.

\subsection{Motivasi Kerja}

Motivasi dalam diri seseorang akan mendorong untuk melakukan sesuatu yang menjadi tanggung jawabnya dalam dalam rangka pencapaian tujuan dalam lingkungan ia bekerja. Motivasi adalah kekuatan kompleks yang membuat seseorang berkeinginan memulai dan menjaga kondisi kerja dalam organisasi. ${ }^{38}$ Sedangkan menurut Vance dalam Danim motivasi adalah perasaan atau keinginan seseorang yang berada dan bekerja pada kondisi tertentu untuk melaksanakan tindakan-tindakan yang menguntungkan dilihat dari perspektif pribadi dan terutama organisasi. ${ }^{39}$ Sedangkan menurut Soemanto motivasi adalah suatu

\footnotetext{
${ }^{37}$ Peraturan Menteri Pendayagunaan Aparatur Negara dan Reformasi Birokrasi Republik Indonesia Nomor 9 Tahun 2014 : Tentang Jabatan Fungsional Pustakawan dan Angka Kreditnya (Jakarta: Perpustakaan Nasional RI, 2014), h. 4 2004), h.15

${ }^{38}$ Danim S, Motivasi, Kepemimpinan, dan Efektivitas Kelompok (jakarta: Rineka Cipta, 2004), h.15

${ }^{39}$ Danim S, Motivasi, Kepemimpinan, dan Efektivitas Kelompok (jakarta: Rineka Cipta,
} 
perubahan tenaga yang ditandai oleh dorongan efektif dan reaksi-reaksi pencapaian tujuan. ${ }^{40}$

Dari uraian di atas dapat disimpulkan bahwa motivasi adalah keinginan seseorang yang menjadi kekuatan kompleks kemudian menjadi dorongan yang efektif untuk mencapai tujuan tertentu dalam organisasi.

Secara umum, ada dua faktor yang dapat mempengaruhi motivasi individu, yaitu faktor internaldan faktor eksternal.

1. Faktor Internal

Faktor internal merupakan faktor yang mempengaruhi motivasi yang berasal dari dalam diri individu, yang termasuk dalam faktor internal ini antara lain:

a. Persepsi individu

Persepsi individu mengenai dirinya sendiri akan mempengaruhi individu tersebut untuk berprilaku. Artinya, seseorang termotivasi atau tidak untuk melakukan sesuatu banyak tergantung pada proses konngnitif berupa persepsi. Persepsi seseorang tentang dirinya sendiri akanmendorong danmengarahkan atau memotivasi prilaku orang tersebut untuk bertindak.

b. Harga diri dan prestasi

Faktor ini mendorong atau mengarahkan individu untuk berusaha agar menjadi pribadi yang mandiri, kuat danmemperoleh kebebasan

\footnotetext{
${ }^{40}$ Soemanto, Psikologi Pendidikan ( Jakarta: Bina Aksara 1987), h.32
} 
serta mendapatkan status tertentu dalam lingkungan masyarakat, serta dapat mendorong individu untuk berprestasi yang muncul dari dalam diri individu akan menjadi kekuatan bagi individu untuk termotivasi dalam berprilaku.

c. Harapan

Harapan ini merupakaninformasi objektif dari lingkungan yang mempengaruhi sikap dan perasaan subjektif seseorang. Harapan dapat mempengaruhi motivasi seseorang dalam berprilaku, karena harapan merupakan tujuan dari prilaku itu sendiri.

d. Kebutuhan

Manusia dimotivasi oleh kebutuhan untukmenjadikan dirinya sendiri yang berfungsi secara penuh,sehingga mampu meraih potensi secara total. Kebutuhan akan mendorong dan mengarahkan seseorang untuk mencari atau menghindari,mengarahkan dan memberi respon terhadap tekanan yang dialaminya.

e. Kepuasan

Kepuasan lebih merupakan suatu dorongan afektif yang muncul dalamdiri individu untuk mencapai goal atau tujuan yang di inginkan dari suatu perilaku.

2. Faktor Eksternal

a. Jenis dan sifat pekerjaan

Dorongan untuk bekerja pada jenis dan sifat pekerjaan tertentu sesuai dengan objek pekerjaan yang tersedia akan mengarahkanindividu untuk menentukan sikap 
atau pilihan pekerjaan yang ditekuni. Kondisi ini juga dapat dipengaruhi oleh sejauh mana nilai imbalan yang dimiliki oleh objek pekerjaan dimkasud.

b. Kelompok kerja dimana individu bergabung Kelompok kerja atau organisasi tempat dimana individu bergabung dapat mendorong atau mengarahkan prilaku individu dalam mencapai suatu tujuan prilaku tertentu. Peranan kelompok atau organisasi ini dapat membantu individu sehubungan dengan kiprahnya dengan kehidupan sosial.

c. Situasi lingkungan

Setiap individu terdorong untuk berhubungan dengan rasa mampunya dalam melakukan interaksi secara efektif dengan lingkungannya.

d. Sistem reward yang diterima

Reward merupakan karakteristik atau kualitas dari objek pemuas yang dibutuhkan oleh seseorang yang dapat mempengaruhi motivasi atau dapat mengubah arah tingkah laku dari satu objek ke objeklain yang mempunyai nilai reward yang lebih baik. Sistem pemberian reward dapat mendorong individu untuk berprilaku dalam mencapai tujuan. Prilaku dipandang sebagai tujuan sehingga ketika tujuan tercapai maka akan timbul reward.

\section{Metodelogi Penelitian}

Penelitian ini menggunakan jenis penelitian kuantitatif, dengan tujuan deksriptif yaitu penelitian yang menjabarkan suatu fenomena 
secara jelas berdasarkan pada data tetap berupa angka dan diolah dengan perhitungan statistik.

karena dalam analisinya menggunakan data yang diperoleh melalui penyebaran angket. Penelitian kuantitaif adalah suatu penelitian yang mengguankan pendekatan dengan pemecahan masalah yang berhubungan dengan konsep kuantifikasi, disiapkan dengan cermat untuk melakukan pengukuran dan evaluasi. ${ }^{41}$

Sumber data yang digunakan dalam penelitian ini ada dua sumber yaitu: Sumber Data Primer, sumber data primer berasal dari data yang diperoleh dengan cara melakukan pembagian kuesioner kepada responden yaitu pustakawan di perpustakaan IAIN Curup . Sumber Data Sekunder yang diperoleh dari media yang bersumber pada buku perkuliahan atau buku yang menjelaskan mengenai tunjangan fungsional dan motivasi kerja pustakawan, jurnal yang menjelaskan tentang tunjangan fungsional dan motivasi kerja pustakawan, hasil penelitian yang membahas tentang tunjangan fungsional dan motivasi kerja, website yang berisi tentang tunjangan fungsional danmotivasi kerja pustakawan, dan sebagainya yang berhubungan dengan permasalahan yang diangkat dalam penelitian ini.

Populasi dalam penelitian ini yaitu pustakawan yang telah menerima tunjangan fungsional, peneliti mengambil populasi sebanyak 6 orang

${ }^{41}$ Sri Hartinah. Metode Penelitian Perpustakaan. (Tangerang Selatan :

Universitas Terbuka, 2014), h. 2.10. 
pustakawanyang ada di perpustakaan IAIN Curup. Sampel adalah bagian atau contoh kecil yang mewakili sifat dan karakter. ${ }^{42}$ Penelitian ini menggunakan teknik sampling jenuh, yaitu teknik penentuan sampel bila semua anggota populasi di gunakan sebagai sampel.43 Hal ini dilakukan karena jumlah populasi relatif kecil kurang dari 30 orang. Dalam penelitian ini berjumlah 6 orang pustakawan.

Teknik pengumpulan data yang digunakan meliputi: observasi, wawancara, kuesioner, dan dokumentasi. Instrumen penelitian yang digunakan dalam penelitian ini adalah kuisioner/angket. Variabel dalam penelitian terdiri dari dua variabel yaitu variabel independen dan variabel dependen. Variabel independen/ bebas dalam penelitian ini ialah variabel tunjangan fungsional, sedangkan variabel dependen/ terikat adalah motivasi kerja pustakawan di perpustakaan IAIN Curup.

Analisis data dalam penelitian ini yaitu, mentabulasikan data dari angket, dan mencari regresi linier sederhana. Setelah mencari regresi linkier sederhana dilakukan Uji Signifikansi Parsial (Uji T) untuk mengetahui adakah pengaruh atau tidak antara tunjangan fungsional terhadap motivasi kerja pustakawan. Selanjutnya dilakukan Uji Koefisien Determinasi $\left(\mathrm{R}^{2}\right)$ untuk mengetahui seberapa besar pengaruh variabel independen

${ }^{42}$ Helen Sabera Adib. Metodologi Penelitian. (Palembang : Noerfikri, 2015), h. 31.

${ }^{43}$ Sugiyono Metode Penelitian Kuantitatif, Kualitatif Dan R\&D, h. 85 
(tunjangan fungsional) berkontribusi terhadap variabel dependen (motivasi kerja pustakawan).

\section{Hasil dan Pembahasan}

Hasil penelitian ini akan membahas tentang adakah pengaruh tunjangan fungsional terhadap motivasi kerja pustakawan di perpustakaan IAIN Curup dan seberapa besar pengaruh tunjangan fungsional terhadap motivasi kerja pustakawan di perpustakaan IAIN Curup. Hasil dari penelitian ini akan diuraikan sebagai berikut:

Tabel 4.1.

\section{Hasil keseluruhan Sub Variabel}

\begin{tabular}{|c|c|c|c|}
\hline Sub & Butir Pernyataan & Nilai & Kategori \\
\hline \multirow{3}{*}{ Tugas } & $\begin{array}{l}\text { Saya bekerja sesuai } \\
\text { dengan pendidikan dan } \\
\text { bidang kompetensi }\end{array}$ & 3,33 & Sedang \\
\hline & $\begin{array}{l}\text { Untuk menunjang } \\
\text { efektivitas dalam } \\
\text { bekerja saya } \\
\text { menggunakan fasilitas } \\
\text { pelayanan ditempat } \\
\text { kerja }\end{array}$ & 5,16 & $\begin{array}{l}\text { Sangat } \\
\text { Tinggi }\end{array}$ \\
\hline & Jumlah & 8,49 & $x=4,24$ \\
\hline $\begin{array}{l}\text { Tanggung jawab } \\
\text { dan wewenang }\end{array}$ & $\begin{array}{l}\text { Jenjang jabatan } \\
\text { bapak/ibu miliki } \\
\text { disesuaikan dengan }\end{array}$ & 3,33 & Sedang \\
\hline
\end{tabular}




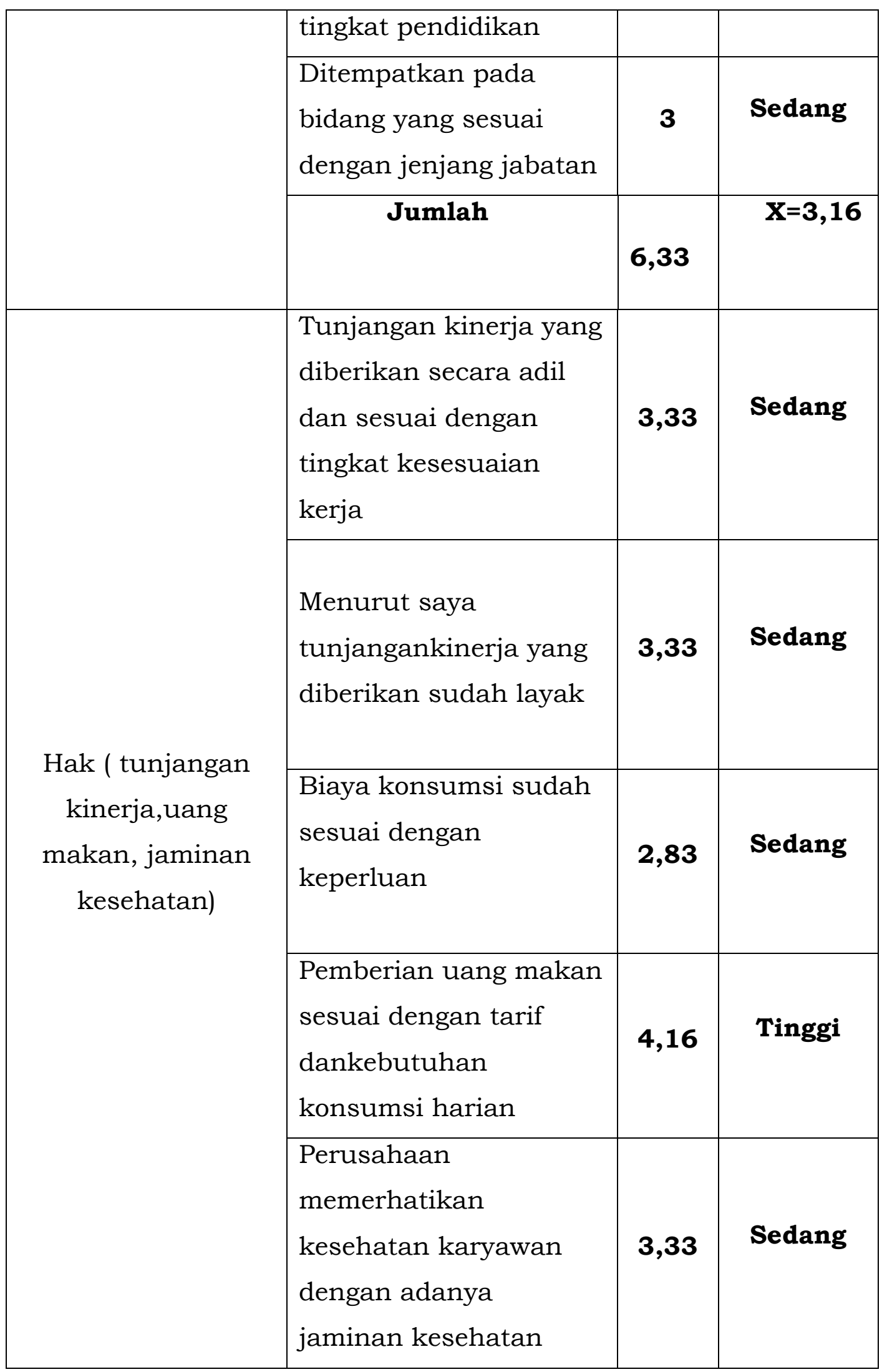




\begin{tabular}{|c|c|c|c|}
\hline & $\begin{array}{l}\text { Dalam menjalankan } \\
\text { pekerjaanya karyawan } \\
\text { mendapatkan } \\
\text { perlindungan } \\
\text { keselamatan dari } \\
\text { perusahaan }\end{array}$ & 3,33 & Sedang \\
\hline & Jumlah & 20,14 & $X=3,35$ \\
\hline \multirow{6}{*}{$\begin{array}{c}\text { Faktor Internal } \\
\text { (persepsi } \\
\text { individu, harga } \\
\text { diri dan } \\
\text { prestasi, } \\
\text { harapan, } \\
\text { kebutuhan, } \\
\text { kepuasan) }\end{array}$} & $\begin{array}{l}\text { Saya mampu menerima } \\
\text { tanggung jawab dan } \\
\text { mengasah potensi diri }\end{array}$ & 3,83 & Tinggi \\
\hline & $\begin{array}{l}\text { Saya berusaha untuk } \\
\text { tetap unggul dalam } \\
\text { bekerja }\end{array}$ & 3,53 & Tinggi \\
\hline & $\begin{array}{l}\text { Saya mampu untuk } \\
\text { bekerja secara mandiri } \\
\text { dan kuat }\end{array}$ & 2,83 & Sedang \\
\hline & $\begin{array}{l}\text { Saya diberi } \\
\text { penghargaan berupa } \\
\text { insentif atas prestasi } \\
\text { yang diraih }\end{array}$ & 3 & Sedang \\
\hline & $\begin{array}{l}\text { Saya selalu } \\
\text { berkeinginan untuk } \\
\text { tetap kreatif dalam } \\
\text { bekerja }\end{array}$ & 3,5 & Tinggi \\
\hline & $\begin{array}{l}\text { Saya berkeinginan } \\
\text { untuk melakukan } \\
\text { pekerjaan dengan } \\
\text { benar agar memperoleh } \\
\text { bonus yang } \\
\text { memuaskan }\end{array}$ & 3,83 & Tinggi \\
\hline
\end{tabular}




\begin{tabular}{|c|c|c|c|}
\hline & $\begin{array}{l}\text { Semakin banyak } \\
\text { kebutuhan saya maka } \\
\text { motivasi kerja saya } \\
\text { semakin tinggi }\end{array}$ & 3,5 & Tinggi \\
\hline & $\begin{array}{l}\text { Saya harus } \\
\text { mengembangkan } \\
\text { pelatihan dan motivasi } \\
\text { kerja dalam memenuhi } \\
\text { kebutuhan saya }\end{array}$ & 3,33 & Sedang \\
\hline & $\begin{array}{l}\text { Saya selalu } \\
\text { menyelesaikan tugas } \\
\text { sesuai target yang telah } \\
\text { ditentukan oleh atasan }\end{array}$ & 3,83 & Tinggi \\
\hline & $\begin{array}{l}\text { Saya selalu berusaha } \\
\text { keras agar produktif } \\
\text { dalam bekerja }\end{array}$ & 3,83 & Tinggi \\
\hline & Jumlah & 35,01 & $x=3,50$ \\
\hline $\begin{array}{c}\text { Faktor eksternal } \\
\text { (jenis dan sifat }\end{array}$ & $\begin{array}{l}\text { Upah yang saya } \\
\text { terimasesuai dengan } \\
\text { pekerjaan }\end{array}$ & 3,66 & Tinggi \\
\hline $\begin{array}{l}\text { kerja dimana } \\
\text { individu bergabung, }\end{array}$ & $\begin{array}{l}\text { Upah yang saya terima } \\
\text { cukup untuk } \\
\text { memenuhi kebutuhan }\end{array}$ & 3,83 & Tinggi \\
\hline $\begin{array}{c}\text { sistem reward yang } \\
\text { diterima) }\end{array}$ & $\begin{array}{l}\text { Saya selalu } \\
\text { berkeinginan untuk } \\
\text { menjalin hubungan } \\
\text { harmonis dengan rekan } \\
\text { kerja agar mencapai } \\
\text { suatu tujuan }\end{array}$ & 2,83 & Sedang \\
\hline
\end{tabular}




\begin{tabular}{|l|l|c|c|}
\hline & $\begin{array}{l}\text { Saya selalu berusaha } \\
\text { untukterlibat aktif } \\
\text { dalam kelompok kerja }\end{array}$ & $\mathbf{3 , 6 6}$ & Tinggi \\
\cline { 2 - 5 } $\begin{array}{l}\text { Saya merasa nyaman } \\
\text { terhadap kondisi } \\
\text { lingkungan kerja }\end{array}$ & $\mathbf{3 , 5}$ & Tinggi \\
\cline { 2 - 5 } & $\begin{array}{l}\text { Saya lebih bisa } \\
\text { berkonsentrasi dalam } \\
\text { bekerja dengan tidak } \\
\text { adanya suara } \\
\text { menganggu ditempat } \\
\text { kerja }\end{array}$ & $\mathbf{3 , 1 6}$ & Sedang \\
\hline $\begin{array}{l}\text { Saya termotivasi untuk } \\
\text { lebih giatlagi dalam } \\
\text { bekerja dengan adanya } \\
\text { pujian dari atasan saya }\end{array}$ & $\mathbf{4}$ & Tinggi \\
\hline $\begin{array}{l}\text { Saya diberi } \\
\text { penghargaan (reward) } \\
\text { atas prestasi yang } \\
\text { diraih }\end{array}$ & $\mathbf{2 , 8 3}$ & Sedang \\
\hline & $\mathbf{2 7 , 4 7}$ & $\mathbf{X = 3 , 4 3}$ \\
\hline
\end{tabular}

Sumber: data primer yang diolah

Berdasarkan Tabel 4.1 menunjukkan bahwa nilai rata-rata dari setiap sub variabel yang adalah sebagai Berikut : 1) Tugas diperoleh dengan nilai rata-rata sebesar 4,24 dengan kategori sanggat tinggi. 2) Tanggung jawab dan wewenang diperoleh dengan nilai rata-rata sebesar 3,16 dengan kategori sedang. 3) Hak ( tunjangan kinerja,uang makan, jaminan kesehatan) diperoleh dengan nilai rata-rata 3,35 dengan kategori sedang. 4) Faktor Internal (persepsi individu, harga diri dan prestasi, harapan, 
kebutuhan, kepuasan) diperoleh dengannilai rata-rata 3,50 dengan kategori tinggi. 5) Faktor eksternal (jenis dan sifat pekerjaan,kelompok kerja dimana individu bergabung, situasi lingkungan, sistem reward yang diterima) diperoleh dengan nilai rata-rata 3,43 dengan kategori tinggi.

\section{Uji Signifikan Parsial (Uji T)}

Uji signifikan dilakukan untuk mengetahui pengaruh secara signifikan antara variabel independen $(\mathrm{X})$ terhadap variabel dependen $(\mathrm{Y})$. Jika nilai thitung $>t_{\text {tabel }}$ dan nilai signifikan lebih < 0,1 maka hipotesis diterima, dan dapat disimpulkan variabel independen $(\mathrm{X})$ berpengaruh secara signifikan terhadap variabel dependen $(\mathrm{Y})$.

Dalam penelitian ini didapatkan tabel dengan ketentuan $\mathrm{a}=0,1(10 \%)$ dan $\mathrm{df}=\mathrm{n}-\mathrm{k}(6-2)=4$ diperoleh nilai tabel sebesar 1,533. Untuk mengetahui hasil uji t dalam penelitian ini peneliti menggunakan program SPSS versi 22 yang dapat dilihat pada tabel di bawah ini :

Tabel 4.2

Uji Signifikan Parsial (Uji T)

\begin{tabular}{|c|c|c|c|c|c|}
\hline \multirow[b]{2}{*}{ Model } & \multicolumn{2}{|c|}{$\begin{array}{l}\text { Unstandardized } \\
\text { Coefficients }\end{array}$} & \multirow{2}{*}{$\begin{array}{l}\text { Standardiz } \\
\text { ed } \\
\text { Coefficient } \\
\text { s } \\
\text { Beta }\end{array}$} & \multirow[b]{2}{*}{$\mathrm{T}$} & \multirow[b]{2}{*}{ Sig. } \\
\hline & B & Std. Error & & & \\
\hline $\begin{array}{ll}1 & \text { (Consta } \\
& \mathrm{nt})\end{array}$ & -1.840 & 5.971 & & -.308 & .773 \\
\hline
\end{tabular}




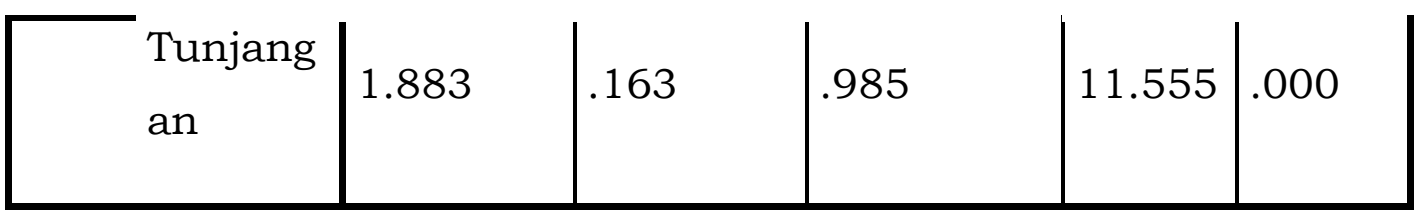

Sumber data: data primer yang diolah,2019

Berdasarkan hasil perhitungan pada tabel 4.2 di atas dapat disimpulkan bahwa, pada tabel Coefficients menunjukkan bahwa variabel (X) tunjangan fungsional memiliki nilai thitung sebesar 11,555 artinya memiliki nilai positif, dan dapat dilihat thitung $>t_{\text {tabel }}$ $(11,555>1$, 533) serta nilai signifikan $000<0,1$. Maka dapat disimpulkan bahwa hipotesis (Ha) diterima, yang berarti variabel tunjangan fungsional berpengaruh positif dan signifikan terhadap variabel motivasi kerja pustakawan di Perpustakaan IAIN Curup. ${ }^{44}$

\section{Analisis Koefisien Determinasi $\left(\mathbf{R}^{2}\right)$}

Uji koefisien determinasi dilakukan untuk mengetahui sejauh mana variabel bebas dapat menjelaskan variasi pada variabel terikat, atau dapat juga dikatakan sejauh mana kemampuan seluruh variabel bebas dapat menjelaskan variasi dari variabel terikat. Adapun hasil perhitungan dari uji koefisien determinasi dengan menggunakan bantuan program SPSS versi 22 sebagai berikut:

Tabel 4.40

Hasil Uji Koefisien Determinasi

\begin{tabular}{|l|l|l|l|l|}
\hline Model & $\mathrm{R}$ & $\begin{array}{l}\mathrm{R} \\
\text { Square }\end{array}$ & $\begin{array}{l}\text { Adjusted R } \\
\text { Square }\end{array}$ & $\begin{array}{l}\text { Std. Error of } \\
\text { the Estimate }\end{array}$ \\
\hline 1 & $.985 \mathrm{a}$ & .971 & .964 & 5.462 \\
\hline
\end{tabular}

Sumber: Hasil Perhitungan dengan SPSS

\footnotetext{
${ }^{44}$ Hasil Data Output SPSS versi 22, Uji Signifikan Parsial (Uji T), 2019
} 
Berdasarkan Model Summary pada tabel 4.40 di atas menjelaskan bahwa $R=0,985$, hal ini menunjukkan nilai koefisien antara tunjangan fungsional $(\mathrm{X})$ terhadap motivasi kerja pustakawan(Y). Selanjutnya nilai $R$ Square $\left(R^{2}\right)=0,971$, jika nilai tersebut dipersentasikan maka menjadi 97,1\%. Dalam hal ini besarnya pengaruh antara tunjangan fungsional terhadap motivasi kerja pustakawan di perpustakaan IAIN Curup sebesar 97,1\% dan sisanya $\mathbf{2 , 9 \%}$ dipengaruhi oleh variabel lain di luar model regresi.

\section{Kesimpulan dan Saran}

\section{$5.1 \quad$ Kesimpulan}

Berdasarkan rumusan masalah yang telah disusun dan perolehan data yang sudah diolah pada bab IV yaitu hasil dan pembahasan, maka dapat dirumuskan kesimpulan mengenai adakah pengaruh tunjangan fungsional terhadap motivasi kerja pustakawan dan seberapa besar pengaruh tunjangan fungsional terhadap motivasi kerja pustakawan di Perpustakaan IAIN Curup, yang akan diuraikan sebagai berikut:

1. pengaruh tunjangan fungsional terhadap motivasi kerja pustakawan di perpustakaan IAIN Curup berdasarkan hasil olahan data yang telah dilakukan terdapat pengaruh yang positif, dan terdapat pengaruh yang signifikan antara tunjangan fungsional terhadap motivasi kerja pustakawan di perpustakaan IAIN Curup. Jadi, hipotesis Ha diterima dan hipotesis $\mathrm{H}_{0}$ ditolak, yang berarti terdapat pengaruh positif dan signifikan antara tunjangan fungsional terhadap 
motivasi kerja pustakawan diperpustakaan IAIN Curup.

2. Adapun nilai koefisien determinasi besar pengaruh tunjangan fungsional terhadap motivasi kerja pustakawan dapat dilihat dari nilai koefisien determinasi $\left(R^{2}\right)$ atau $R_{\text {square }}$ sebesar 0,971 atau 97,1\%. Hal ini berarti bahwa 97,1\% variasi motivasi kerja pustakawan di perpustakaan IAIN Curup dipengaruhi oleh tunjangan fungsional, sedangkan sisanya sebesar 2,9\% merupakan pengaruh dari faktor lain di luar faktor yang diteliti.

\subsection{Saran}

Berdasarkan hasil dan pembahasan serta kesimpulan yang telah diuraikan dalam penelitian ini, peneliti mengajukan beberapa saran diantaranya sebagai berikut:

1. Bagi Pustakawan Perpustakaan IAIN Curup

Diharapakan untuk lebih semangat lagi dalam bekerja karena sudah menerima tunjangan fungsional, serta dapat meningkatkan pelayanan-pelayanan yang dibutuhkan oleh pemustaka.

2. Bagi Penelitian Selanjutnya

Diharapkan peneliti selanjutnya dapat mengembangkan penelitian ini dengan cara mencari teori yang lain, baik teori tunjangan fungsional maupun teori motivasi kerja pustakawan agar dapat menghasilkan temuantemuan baru, selain dari penelitian ini. Untuk dapat memperluas jangkauan penelitian, 
dianjurkan memperbanyak sumber referensi seperti jurnal atau buku yang bersangkutan dengan penelitian yang ingin dikaji. 


\section{DAFTAR PUSTAKA}

Undang-Undang dan Standar Nasional Perpustakaan

Peraturan Menteri Pendayagunaan Aparatur Negara dan Reformasi Birokrasi Republik Indonesia Nomor 9 Tahun 2014 Tentang Jabatan Fungsional Pustakawan dan Angka Kreditnya. 2007. Jakarta : Perpustakaan Nasional RI.

Peraturan Pemerintah Nomor 71 Tahun 2013: Tentang Tunjangan Jabatan Fungsional Pustakawan. 2013. Jakarta : Perpustakaan Nasional RI.

UU Republik Indonesia No. 43 Tahun 2007 Tentang perpustakaan. 2010. Jakarta : Perpustakaan Nasional RI.

Buku

Alhamdu fara hamdana. 2017. psikologi umum. Palembang: Noerfikri offset.

Helen Sabera Adib. 2015. Metodologi Penelitian. Palembang : Noerfikri.

Hermawan Rachman dan Zulfikar Zen. 2006. Etika Kepustakawanan: Suatu Pendekatan terhadap Kode Etik Pustakwan Indonesia. Jakarta: Sagung Seto.

S, Danim. 2004. Motivasi, Kepemimpinan, dan Efektivitas Kelompok. Jakarta: Rineka Cipta.

Sri Hartinah. 2014. Metode Penelitian Perpustakaan. Tangerang Selatan : Universitas Terbuka.

Sugiyono. 2016. Metode Penelitian Kuantitatif, Kualitatif Dan R\&D. Bandung : Alfabeta.

Tim Penyusun Kamus Pusat Bahasa. 2002. Kamus Besar Bahasa Indonesia. Jakarta : Balai Pustaka.

Wursanto IG. 1989. Manajemen Kepegawaian I. Yogyakarta: Kanisius. 